\title{
Electrogenic capabilities of gram negative and gram positive bacteria in microbial fuel cell combined with biological wastewater treatment
}

\author{
${ }^{1}$ *D. F. Juang; ${ }^{2}$ P. C. Yang; ${ }^{1}$ C. H. Lee; ${ }^{1}$ S. C. Hsueh; ${ }^{3}$ T. H. Kuo \\ ${ }^{1}$ Department of Health Business Administration, Meiho University, 23, Pingguang Rd., Neipu, Pingtung 912, \\ Taiwan, R.O.C. \\ ${ }^{2}$ Otorhinolaryngologic Department, Cheng Ching General Hospital, 24F, 230, Ming Chuan Second Road, Kaohsiung \\ 806, Taiwan, R.O.C \\ ${ }^{3}$ New Taipei City Hospital Banqiao Branch, 198, Yingshi Rd., Banqiao Dist., New Taipei City 220,Taiwan, R.O.C. \\ Received 6 February 2011; revised 8 May 2011; accepted 10 August 2011; available online 1 September 2011

\begin{abstract}
The voltage and the power production of two gram negative and two gram positive bacteria in four identical continuous flow microbial fuel cells combined with biological wastewater treatment units were evaluated and compared in the present study. Each microbial fuel cell and biological treatment unit was operated at four different flow rates and four different external load resistances. The results show that overall removal efficiency of chemical oxygen demand for all four systems can reach more than $85.5 \%$. Each pure culture has different power generation performance that can be affected by some factors, such as wastewater characteristics, influent flow rate and hydraulic retention time of reactor. Good linear relationships between the flow rate and the potential and between the flow rate and the power density on four pure cultures at different external load resistances were found. Comamonas testosteroni has better power generation performance than Arthrobacter polychromogenes, especially at higher flow rate. Although Pseudomonas putida also showed higher power generation than Corynebacterium glutamicum, the difference was not statistically significant. It seems that gram negative bacteria could display higher power generation than gram positive bacteria at higher flow rate. However, more evidence is required to provide stronger proof for the difference of power generation between gram negative and gram positive bacteria.
\end{abstract}

Keywords: Anode; Cathode; Electron; Power generation; Proton

\section{INTRODUCTION}

Microbial fuel cells (MFCs) have been considered a promising technology for power generation (Logan and Regan, 2006; Refaat, 2009; 2010; Chen et al., 2010; Lee and Shih, 2010). In MFCs, the microorganisms are able to convert the organic matter in wastewater into electricity. In a biological wastewater treatment system, if an anaerobic tank that acts as an anodic chamber is provided, the bacteria will use the organic matter in this tank to produce electrons and protons. The electrons will then be diverted toward an anode and subsequently flow across a conductive material containing a resistor and finally be released in a cathodic chamber. The protons will also be transported to the cathodic chamber through the Proton exchange membrane (PEM). Both electrons

* *orresponding Author Email: x00002060@email.meiho.edu.tw Tel.: +88687799 821; Fax: +88687780673 and protons will finally be depleted in the cathodic chamber, coupled with the reduction of oxygen to water (Rabaey and Verstraete, 2005; Logan and Regan, 2006). Many researchers have used different species of pure culture in MFCs to generate electricity using this technique. Bond and Lovely (2003) studied the power generation performance of Geobactor sulfurreducens and reported that production of current in MFC $\left(65 \mathrm{~mA} / \mathrm{m}^{2}\right.$ of electrode surface $)$ or poisedpotential $\left(163-1143 \mathrm{mV} / \mathrm{m}^{2}\right)$ mode was greater than that reported in previous studies. Rabaey et al. (2004) also claimed that the average power densities were $23.3 \pm 6.2 \mathrm{~W} / \mathrm{m}^{2}$ of anode for Pseudomonas aeruginosa, $4.9 \pm 1.8 \mathrm{~W} / \mathrm{m}^{2}$ of anode for isolate KRA1 and $28.4 \pm 2.3 \mathrm{~W} / \mathrm{m}^{2}$ of anode for isolate KRA3. They also concluded that the pure cultures yield lower power outputs than the mixed consortium. Min et al. 
(2005) compared the power generation performance between a pure culture, Geobactor metallireducens and a mixed culture, and reported power output of $40 \pm 1 \mathrm{~mW} / \mathrm{m}^{2}$ for the former and $38 \pm 1 \mathrm{~mW} / \mathrm{m}^{2}$ for the latter. Du et al. (2007) transferred a mixed culture from anaerobic sludge into an MFC and found that the microorganisms with electrophilic and anode-preferred characteristics will appear in the anodic chamber more often. Sun et al. (2009) also found that higher power density can be obtained more easily by a mixed culture than a pure culture in MFCs.

Many researchers have also analyzed the power generation performance of MFC using gram negative pure cultures, such as Escherichia coli (Schroder et al., 2003; Zhang et al., 2008), Shewanella putrefaciens (Kim et al., 1999; Kim et al., 2002), Shewanella oneidensis (Biffinger et al., 2008; Watson and Logan, 2010) and Rhodoferax ferrireducens (Chaudhuri and Lovley, 2003). Likewise, some researchers have studied the power generation performance of MFC using gram positive bacteria, such as Clostridium butyricum EG3 (Park et al., 2001), Enterococcus gallinarum (Rabaey et al., 2004), Methanothermobacter thermauto-trophicus, Pelotomaculum thermopropionicum, Brevibacilus agri (fermicutes) (Debabov, 2008), Clostridium acetobutylicum, and Clostridium thermohydrosulfuricum (Mathuriya and Sharma, 2009; Finch et al., 2011).

Gram positive bacteria have simpler chemical composition containing approximately $90 \%$ peptidoglycan and $10 \%$ teichoic acid. The covalent bonding between peptidoglycan and teichoic acid may cause higher surface Zeta potential (negative surface charge) of many gram positive bacteria (Juang, 2001). On the contrary, the cell wall of gram negative bacteria contains peptidoglycan (approximtely $10 \%$ ), an outer membrane (composed of lipopolysaccharide, lipophosphate and lipoprotein), an outer membrane protein and periplasm. Therefore, most gram negative bacteria appear to have lower surface Zeta potential. It is possible that the difference of cell surface charges between gram negative and gram positive bacteria may affect their electrogenic capability in MFC. By the way, the difference of growth rates between gram negative and gram positive bacteria may also affect their power output in MFC. However, before the possible factors affecting the power generation capability of gram negative and gram positive bacteria in MFC are identified, it will be of great interest to first determine whether both types of bacteria display different power generation performance under the same operational conditions. This study was conducted at the laboratory of Meiho University in Taiwan from November 2010 to January 2011.

\section{MATERIALS AND METHODS}

\section{Pure cultures}

Four kinds of pure cultures were selected in this study, including two gram negative bacteria (Pseudomonas putida and Comamonas testosteroni) and two gram positive bacteria (Arthrobacter polychromogenes and Corynebacterium gultamicum). These pure cultures were purchased from the Bioresource Collection and Research Center in Taiwan, and were incubated in our laboratory. Before the bacteria were transferred into four MFCs, they were individually incubated in the disinfected artificial wastewater $(250 \mathrm{~mL}$ for each bacterium) without aeration for two weeks to adapt to the wastewater and to rapidly increase their population.

\section{Artificial wastewater}

During the experimental period for P. putida and Corynebacterium gultamicum, the compositions and concentrations of artificial wastewater were 1,000 $\mathrm{mg} / \mathrm{L}$ of glucose, $300 \mathrm{mg} / \mathrm{L}$ of nutrient broth, 167 $\mathrm{mg} / \mathrm{L}$ of $\mathrm{NH}_{4} \mathrm{CL}, 25 \mathrm{mg} / \mathrm{L}$ of $\mathrm{K}_{2} \mathrm{HPO}_{4}, 25 \mathrm{mg} / \mathrm{L}$ of $\mathrm{NaH}_{2} \mathrm{PO}_{4}, 5 \mathrm{mg} / \mathrm{L}$ of $\mathrm{FeCL}_{3}, 100 \mathrm{mg} / \mathrm{L}$ of $\mathrm{MgCL}_{2}, 10$ $\mathrm{mg} / \mathrm{L}$ of $\mathrm{MnSO}_{4}$, and $133 \mathrm{mg} / \mathrm{L}$ of $\mathrm{CaCL}_{2}$; however, two more compositions of $25 \mathrm{mg} / \mathrm{L}$ of $\mathrm{NaOH}$ and 175 $\mathrm{mg} / \mathrm{L}$ of $\mathrm{NaHCO}_{3}$ were provided during the experimental period for Comamonas testosteroni and A. polychromogenes, respectively, to adjust for different pHs of wastewater (Juang, 2001; Eldiwani et al., 2009). The artificial wastewater was autoclaved, and the delivery tube was disinfected by $95 \%$ ethyl alcohol before each use.

\section{MFC design}

For each MFC system, two graphite carbon electrodes (CCM-400C, Central Carbon Co., Ltd., Taiwan) with the same size were used for both anode and cathode $(6.3 \mathrm{~cm}$ length $\times 4 \mathrm{~cm}$ width $\times 3 \mathrm{~mm}$ 
thickness). Both anodic and cathodic chambers were made of Plexiglas acrylic sheets with effective water volume of $797 \mathrm{~cm}^{3}(8.3 \mathrm{~cm}$ side water depth $\times 9.8 \mathrm{~cm}$ width $\times 9.8 \mathrm{~cm}$ length) for each chamber. Every chamber was disinfected with $95 \%$ ethyl alcohol before use. The anodic chamber was sealed with superglue. Finally, the cover and all connections were sealed with silica gel to maintain an anaerobic condition in the chamber during operation. A peristaltic pump was used to pump fixed amount of artificial wastewater into each anodic chamber. The effluent of anodic chamber first flowed into a water seal box before overflowing into a biological treatment unit (including the aeration tank and the secondary clarifier) to ensure that the air will not reflux into the anodic chamber. A tube connected from the anodic chamber into a bottle filled with water to form a water seal was used to discharge any gases produced by the anaerobic reaction. Air was purged into each cathodic chamber by an air stone connected to a blower to supply oxygen needed for the electrochemical reaction. The dissolved oxygen concentration was maintained in the range of 7.1$7.5 \mathrm{mg} / \mathrm{L}$. The cathodic chamber was filled with 30.8 $\mathrm{mM}$ of $\mathrm{KH}_{2} \mathrm{PO}_{4} \cdot \mathrm{H}_{2} \mathrm{O}$ solution (adjusted to $\mathrm{pH}$ of approximately 7.0 by $1.0 \mathrm{~N} \mathrm{HNO}_{3}$ ) and aerated water as the cathodic electrolyte. The sludge in anodic chamber was mixed by a stirrer; however, the mixing was only provided by aeration in cathodic chamber. Fig. 1 shows the diagram of an MFC combined with a biological wastewater treatment process in the present study.

The anodic and cathodic chambers were separated by a proton exchange membrane (Nafion 117, Dupont Co., USA) installed in a Plexiglas acrylic pipe (inner diameter $1.5 \mathrm{~cm}$ and total length $23 \mathrm{~cm}$ ) connecting anodic and cathodic chambers. The distance between anode and cathode was approximately $36.5 \mathrm{~cm}$. The anode and the cathode were connected externally with concealed copper wire and the power

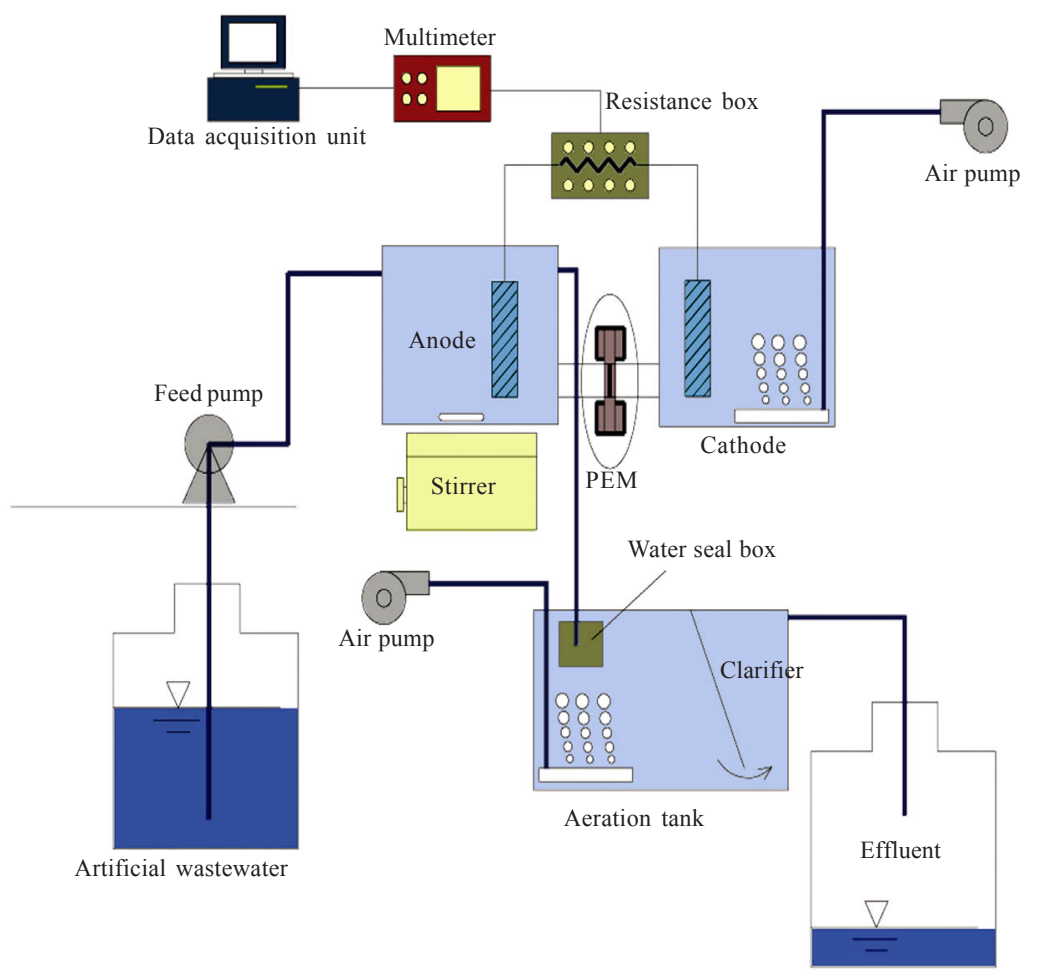

Fig. 1: Schematic of an MFC combined with a biological wastewater treatment process 
production was measured with the external load resistance adjusted to $10,50,500$, and $1000 \Omega$ using a resistor box.

\section{Operational condition}

The MFCs were operated at an ambient temperature of $24-26^{\circ} \mathrm{C}$ in the laboratory. All systems were run under identical continuous flow conditions with the flow rates of $350 \mu \mathrm{L} / \mathrm{min}(0.5 \mathrm{~L} /$ day $), 700 \mu \mathrm{L} / \mathrm{min}(1.0 \mathrm{~L} /$ day), $1000 \mu \mathrm{L} / \mathrm{min}(1.44 \mathrm{~L} /$ day $)$ and $2000 \mu \mathrm{L} / \mathrm{min}(2.88$ $\mathrm{L} /$ day) to compare the differences of power generation between gram negative and gram positive bacteria. The Hydraulic retention times (HRTs) for anodic chamber were $38.3,19.1,13.3$ and $6.6 \mathrm{~h}$, respectively, whereas HRT for biological treatment aeration tank were 47.0, 23.5, 15.7 and $8.2 \mathrm{~h}$, respectively. Stable substrate removal efficiency expressed as Chemical oxygen demand (COD) and power output were considered as indicators to assess the stable performance of the MFCs. The flow rate was set to $350 \mu \mathrm{L} / \mathrm{min}$ first, and the potential (voltage) of each MFC (each pure culture) was measured a minimum of five times per week with the external load resistance adjusted to $10,50,500$ and $1000 \Omega$ until the system was stable. At the last two days, when the power outputs became stable, the synthetic wastewater (influents) and the effluents from anodic chamber and clarifier were collected for analysis. The average of the COD values and the power outputs were used for further analysis. In the same way, the power production and the water quality of MFCs for each bacterium under the flow rates of 700, 1000, and 2000 $\mu \mathrm{L} / \mathrm{min}$ were evaluated. Table 1 shows the operational data of MFC and biological treatment unit in the present study.

Table 1: Operational data of MFC and biological treatment unit

\begin{tabular}{lcc}
\hline Systems & Flow rate $(\mu \mathrm{L} / \mathrm{min})$ & HRT $(\mathrm{h})$ \\
\hline & 350 & 38.3 \\
MFC & 700 & 19.1 \\
& 1000 & 13.3 \\
& 2000 & 6.6 \\
Biological treatment unit & 350 & 47.0 \\
(only aeration tank) & 1000 & 23.5 \\
& 2000 & 15.7 \\
\hline
\end{tabular}

Analysis of water quality and power Generation

Water samples of the influent (artificial wastewater) and the effluents of anodic chamber and secondary clarifier were collected for the measurement of water temperature, $\mathrm{pH}$, conductivity and COD (using closed reflux method), following the methods mentioned in Standard Methods (Clesceri et al., 2001). The pH, temperature, conductivity, and dissolved oxygen (DO) (DO200, YSI, Inc., USA) of the water in cathodic chamber were also measured. For the confirmation of experimental accuracy, each experimental analysis was applied to each water sample in duplicate, and the data from duplicated tests of each water sample were then averaged.

The potentials were measured using a digital multimeter with data acquisition unit (U1253B, Agilent Technologies, Malaysia) and converted to power $(\mathrm{mW})$ and power density $\left(\mathrm{mW} / \mathrm{m}^{3}\right.$ of anodic chamber). When the MFCs became stable (5-7 d), the potentials at various load resistances $(10,50,500$ and $1000 \Omega$ ) were measured a minimum of five times per week. As the reading of potential on the digital multimeter became stable during each measurement, the potentials were then recorded every $10 \mathrm{~s}$ continuously for $3 \mathrm{~min}$, then averaged. All the average potentials were collected continuously for several days (5-14 d) (Tables 3-6), and used for further analysis. All statistical data analyses were performed using the SPSS 13.0 software.

\section{RESULTS AND DISCUSSION}

\section{Wastewater treatment efficiency}

The treatment efficiencies and the substrate degradation rates of the MFCs combined with a biological wastewater treatment unit (including aeration tank and secondary clarifier) for four cultures are outlined in Table 2. The measured influent CODs of MFCs were between 1060 and 1371 $\mathrm{mg} / \mathrm{L}$. The $\mathrm{pH}$ values of artificial wastewater for $P$. putida and Corynebacterium glutamicum were in the range of 5.78-6.36, which caused the low $\mathrm{pH}$ values (i.e., 3.26-4.38) in the effluents of both anodic chambers. However, after the addition of $\mathrm{NaOH}$ and $\mathrm{NaHCO}_{3}$ into artificial wastewater, the influent $\mathrm{pH}$ values for Comamonas testosteroni and $A$. polychromogenes ranged from 8.11 to 8.66 , and the effluent $\mathrm{pH}$ values of anodic cell ranged from 6.01 to 6.67. According to the data in Table 2, the COD 
Int. J. Environ. Sci. Tech., 8 (4), 781-792, Autumn 2011

Table 2: COD removal efficiencies and substrate degradation rates at different flow rates in four MFCs

\begin{tabular}{|c|c|c|c|c|c|}
\hline \multirow[b]{2}{*}{ Systems } & Flow rate $(\mu \mathrm{L} / \mathrm{min})$ & 350 & 700 & 1000 & 2000 \\
\hline & Treatment unit & \multicolumn{4}{|c|}{$\begin{array}{l}\text { COD removal efficiency }(\%) / \text { Substrate degradation rate }(\mathrm{kg} \\
\qquad \mathrm{COD} / \mathrm{m}^{3} \text { of treatment unit/day) }\end{array}$} \\
\hline \multirow{3}{*}{$\begin{array}{l}\text { MFC } 1 \\
\text { (Pseudomonas putida) }\end{array}$} & Anodic chamber & $74.7 / 0.72$ & $65.4 / 1.09$ & $42.9 / 0.94$ & $38.0 / 1.88$ \\
\hline & Biological treatment unit & $79.6 / 0.16$ & $82.1 / 0.38$ & $89.2 / 0.92$ & $82.9 / 2.06$ \\
\hline & Total & $94.9 /-$ & $93.7 /-$ & $94.1 /-$ & $89.4 /-$ \\
\hline \multirow{3}{*}{$\begin{array}{l}\text { MFC } 2 \\
\text { (Corynebacterium glutamicum) }\end{array}$} & Anodic chamber & $78.5 / 0.75$ & $71.7 / 1.19$ & $58.8 / 1.29$ & $30.8 / 1.52$ \\
\hline & Biological treatment unit & $73.0 / 0.11$ & $69.4 / 0.27$ & $84.4 / 0.62$ & $79.0 / 2.19$ \\
\hline & Total & $94.2 /-$ & $91.3 /-$ & $93.6 /-$ & $85.5 /-$ \\
\hline \multirow{3}{*}{$\begin{array}{l}\text { MFC } 3 \\
\text { (Comamonas testosteroni) }\end{array}$} & Anodic chamber & $50.0 / 0.39$ & $37.0 / 0.50$ & $31.3 / 0.58$ & $26.0 / 1.16$ \\
\hline & Biological treatment unit & $86.4 / 0.27$ & $86.1 / 0.59$ & $97.2 / 1.07$ & $93.5 / 3.08$ \\
\hline & Total & $93.3 /-$ & $91.2 /-$ & $98.1 /-$ & $95.2 /-$ \\
\hline \multirow{3}{*}{$\begin{array}{l}\text { MFC } 4 \\
\text { (Arthrobacter polychromogenes) }\end{array}$} & Anodic chamber & $52.2 / 0.31$ & $43.5 / 0.58$ & $52.9 / 1.04$ & $13.4 / 0.60$ \\
\hline & Biological treatment unit & $86.6 / 0.33$ & $83.8 / 0.52$ & $93.4 / 0.70$ & $96.8 / 3.74$ \\
\hline & Total & $93.8 /-$ & $94.8 /-$ & $96.9 /-$ & $97.2 /-$ \\
\hline
\end{tabular}

removal efficiency and the substrate degradation rate in anodic cells with lower influent $\mathrm{pH}$ values for $P$. putida and Corynebacterium glutamicum were higher than those with higher influent $\mathrm{pH}$ values for Comamonas testosteroni and A. polychromogenes. At lower influent $\mathrm{pH}$ values, the average COD removal efficiencies for P. putida and Corynebacterium glutamicum in anodic chambers decreased as the flow rates increased from 350 to $2000 \mu \mathrm{L} / \mathrm{min}$. On the contrary, the COD degradation rate in anodic chambers increased as the flow rates increased. Similar results were found for Comamonas testosteroni and $A$. polychromogenes, except that the COD degradation rate of $A$. polychromogenes decreased when the flow rate reached $2000 \mu \mathrm{L} / \mathrm{min}$. The data in Table 2 also show that the biological treatment unit can achieve over 70 $\%$ of COD removal efficiency. In the present study, the MFC combined with the biological treatment unit can effectively remove the organic matter from wastewater. The COD in the final effluent from aeration tank and clarifier was always below $100 \mathrm{mg} / \mathrm{L}$ (between 34 and $98 \mathrm{mg} / \mathrm{L}$; data not shown) and the overall COD removal efficiency was higher than $85.5 \%$ (up to $98.1 \%$ ).

\section{Relationship between flow rate and power generation}

As shown in Figs. 2 and 3, good linear relationships between the flow rate and the potential and between the flow rate and the power density on P. putida (MFC 1), Corynebacterium glutamicum (MFC 2), Comamonas testosteroni (MFC 3) and $A$. polychromogenes (MFC 4) at different external load resistances were found. Higher potential and power density were observed at higher flow rate or higher COD loading (average COD loadings were 0.96, 1.67, 2.20 , and $4.94 \mathrm{~kg} \mathrm{COD} / \mathrm{m}^{3}$ anodic chamber per day for flow rates of $350,700,1000$ and $2000 \mu \mathrm{L} / \mathrm{min}$, respectively). However, notably, all slopes of developed straight lines in Figs. 2 and 3 are very slight; therefore, the increase of potential and power density with flow rate may not be significant. As mentioned above, MFCs 1 and 2 displayed higher COD removal efficiencies and substrate degradation rates in anodic chamber than MFCs 3 and 4. However, the power generation was higher in MFCs 3 and 4 than in MFCs 1 and 2. Thus, only a certain part of substrate is used for power generation. This result is in accordance with the conclusion of Rodrigo et al. (2007), who claimed only $0.25 \%$ of the removed COD used for the electricity generation processes. Figs. 2 and 3 also show that the potential and the power production could be low because the external load resistances are low. This result is also in accordance with the findings of Ghangrekar and 

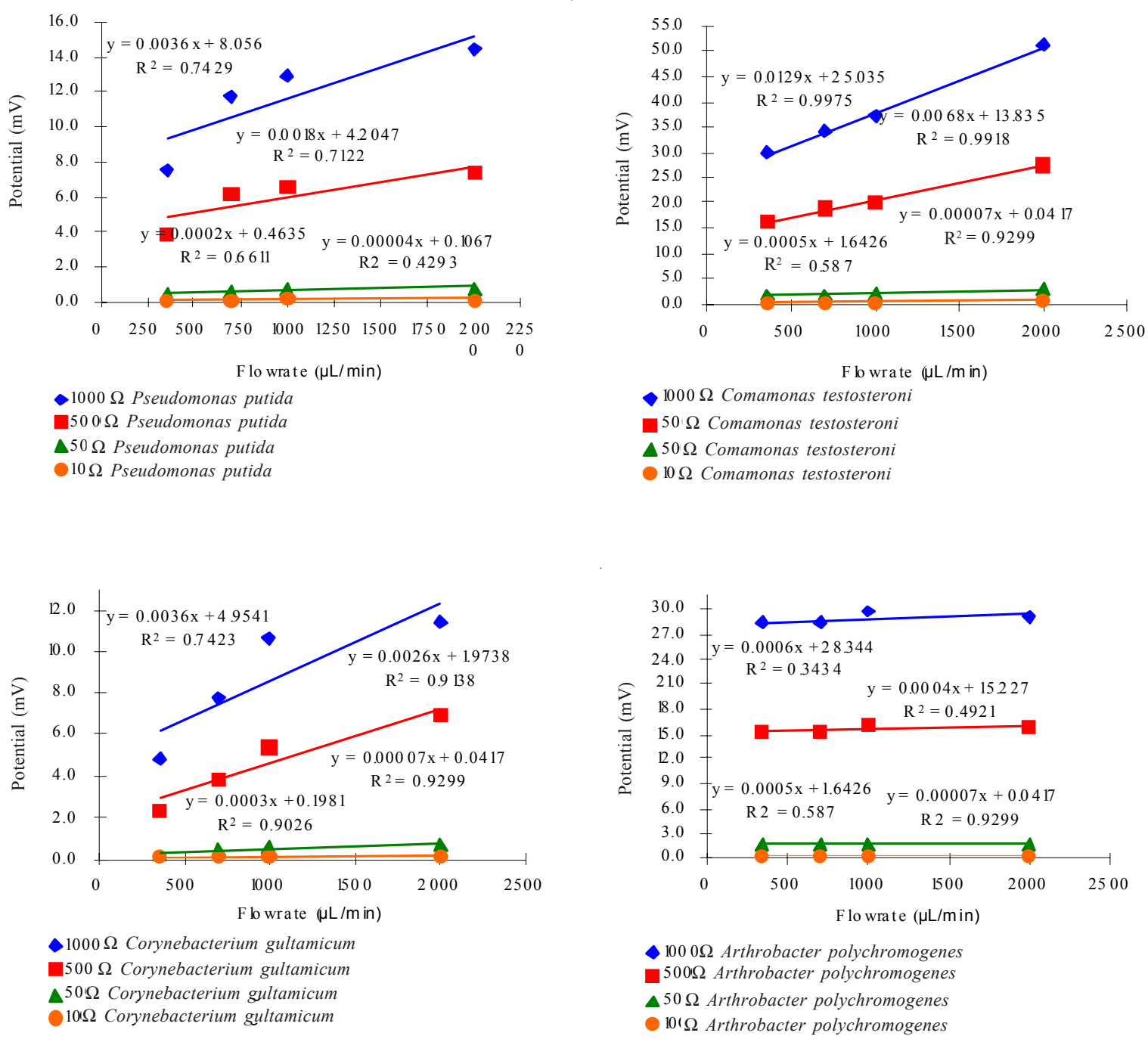

Fig. 2: Relationship between flow rate and potential for gram negative and gram positive bacteria

Shinde (2007) when resistance is less than 1000 Ù.

\section{Statistical analysis of power generation between} gram negative and gram positive bacteria

The comparisons of MFC potentials for each bacterium (four bacteria in total; external load resistance, $1000 \Omega$ ) are listed in Table 3 . The potentials of MFC for P. putida and Corynebacterium glutamicum are apparently irrelevant to flow rate; however, for Comamonas testosteroni and $A$. polychromogenes, higher potentials could be seen at higher flow rates. Table 4 also shows similar results when comparing MFC power densities at different flow rates for each bacterium.

The results were partly different from those obtained by Rodrigo et al. (2007) and Mohan et al. (2010) who reported higher power output at lower substrate load and power density independent of flow rate, respectively. In the study of Mohan et al. (2010), a batch-operated single-chambered MFC and mixed anaerobic consortia were used to treat composite vegetable waste with the loading rates of 2.08, 1.39, and $0.7 \mathrm{~kg} \mathrm{COD} / \mathrm{m}^{3} /$ day. Rodrigo et al. (2007) claimed that the generated power density depends mainly on 

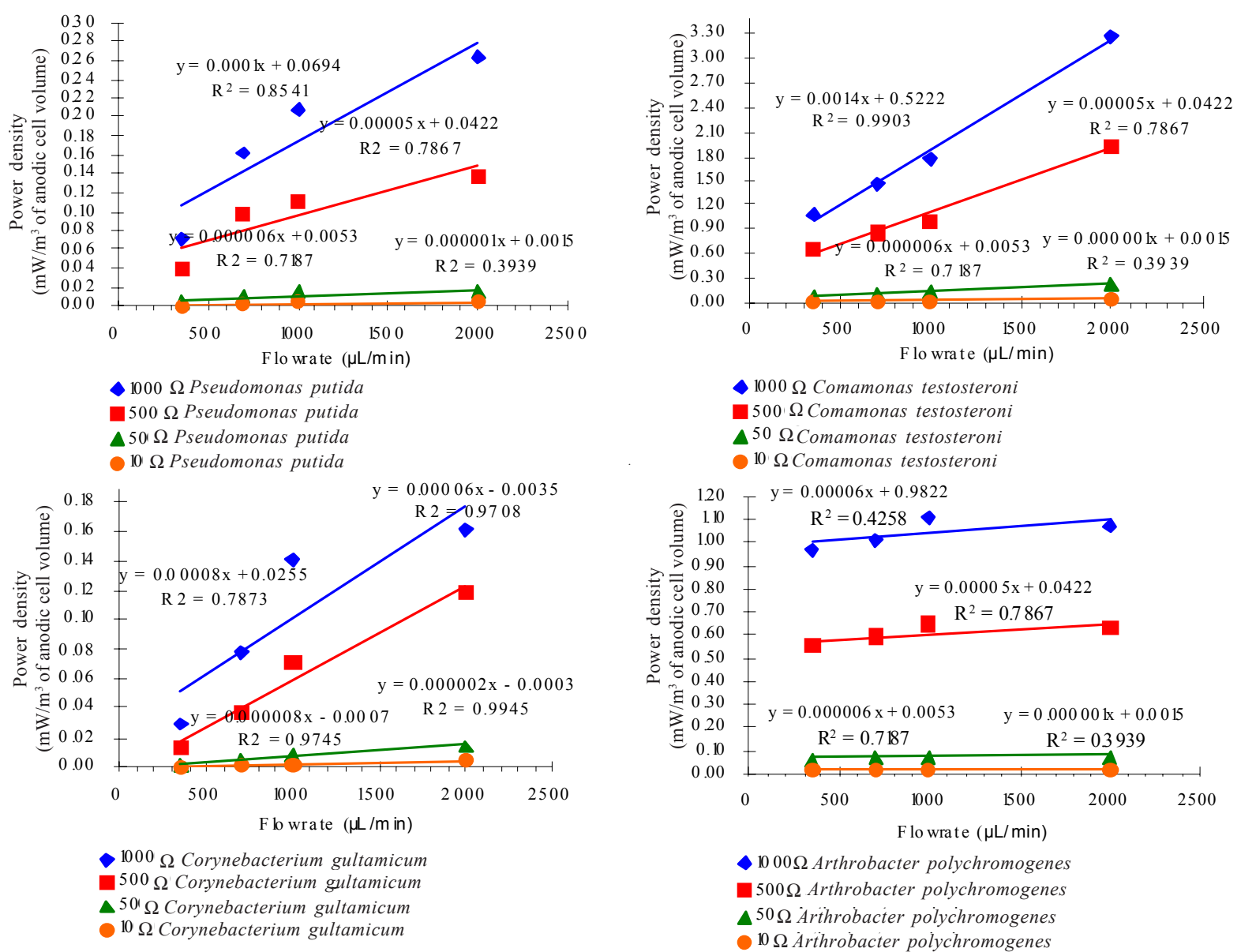

Fig. 3: Relationship between flow rate and power density for gram negative and gram positive bacteria

Table 3: Comparison of MFC potentials at different flow rates for gram negative and gram positive bacteria (external load resistance of 1000 Ù)

\begin{tabular}{|c|c|c|c|c|c|}
\hline \multirow{2}{*}{ Flow rate $(\mu \mathrm{L} / \mathrm{min})$} & \multicolumn{5}{|c|}{ Pseudomonas putida (Gram negative) } \\
\hline & $\mathrm{N}$ & Mean $(\mathrm{mV})$ & S.D. & $\mathrm{p}$ & Scheffe's post hoc test \\
\hline $350(1)$ & 10 & 12.33 & $4.79 \quad 1.419$ & 0.262 & \\
\hline $700(2)$ & 8 & 10.50 & 1.75 & & \\
\hline $1000(3)$ & 5 & 12.64 & 0.38 & & \\
\hline $2000(4)$ & 5 & 14.04 & 0.91 & & \\
\hline \multirow{2}{*}{ Flow rate $(\mu \mathrm{L} / \mathrm{min})$} & \multicolumn{5}{|c|}{ Corvnebacterium glutamicum (Gram positive) } \\
\hline & $\mathrm{N}$ & Mean $(\mathrm{mV})$ & S.D. & $\mathrm{p}$ & Scheffe's post hoc test \\
\hline $350(1)$ & 10 & 7.71 & 0.690 & 0.567 & \\
\hline $700(2)$ & 8 & 7.03 & 1.00 & & \\
\hline $1000(3)$ & 5 & 9.90 & 0.94 & & \\
\hline $2000(4)$ & 5 & 11.79 & 0.93 & & \\
\hline \multirow{2}{*}{ Flow rate $(\mu \mathrm{L} / \mathrm{min})$} & \multicolumn{5}{|c|}{ Comamonas testosteroni (Gram negative) } \\
\hline & $\mathrm{N}$ & Mean $(\mathrm{mV})$ & S.D. $\quad$ F & $\mathrm{p}$ & Scheffe's post hoc test \\
\hline $350(1)$ & 14 & 17.78 & 20.069 & 0.000 & $(4)>(3)=(2)>(1)$ \\
\hline $700(2)$ & 8 & 30.10 & 4.24 & & \\
\hline $1000(3)$ & 5 & 36.33 & 2.91 & & \\
\hline $2000(4)$ & 5 & 43.64 & 7.01 & & \\
\hline \multirow{2}{*}{ Flow rate $(\mu \mathrm{L} / \mathrm{min})$} & \multicolumn{5}{|c|}{ Arthrobacter polychromogenes (Gram positive) } \\
\hline & $\mathrm{N}$ & Mean $(\mathrm{mV})$ & S.D. & $\mathrm{p}$ & Scheffe's post hoc test \\
\hline $350(1)$ & 14 & 14.60 & 13.812 & 0.000 & $(4)=(3)=(2)>(1)$ \\
\hline $700(2)$ & 8 & 26.65 & 1.70 & & \\
\hline $1000(3)$ & 5 & 27.85 & 2.70 & & \\
\hline $2000(4)$ & 5 & 29.27 & 2.74 & & \\
\hline
\end{tabular}


Table 4: Comparison of MFC power densities at different flow rates for gram negative and gram positive bacteria (external load resistance of $1000 \Omega$ )

\begin{tabular}{|c|c|c|c|c|c|c|}
\hline Flow rate $(\mu \mathrm{L} / \mathrm{min})$ & & Pseudor & onasp & tida & & \\
\hline & $\mathrm{N}$ & Power density ( $\mathrm{mW} / \mathrm{m}^{3}$ of anodic chamber) & S.D. & $\mathrm{F}$ & $\mathrm{p}$ & Scheffe's post hoc test \\
\hline $350(1)$ & 10 & 0.22 & 0.17 & 1.223 & 0.323 & \\
\hline $700(2)$ & 8 & 0.14 & 0.04 & & & \\
\hline $1000(3)$ & 5 & 0.20 & 0.01 & & & \\
\hline $2000(4)$ & 5 & 0.25 & 0.32 & & & \\
\hline Flow rate $(\mu \mathrm{L} / \mathrm{min})$ & & Corynebacte & ium $g l$ & amicum & & \\
\hline & $\mathrm{N}$ & Power density ( $\mathrm{mW} / \mathrm{m}^{3}$ of anodic chamber) & S.D. & $\mathrm{F}$ & $\mathrm{p}$ & Scheffe's post hoc test \\
\hline $350(1)$ & 10 & 0.20 & 0.41 & 0.484 & 0.696 & \\
\hline $700(2)$ & 8 & 0.06 & 0.02 & & & \\
\hline $1000(3)$ & 5 & 0.12 & 0.02 & & & \\
\hline $2000(4)$ & 5 & 0.18 & 0.03 & & & \\
\hline$\overline{\text { Flow rate }(\mu \mathrm{L} / \mathrm{min})}$ & & Comamor & as testc & teroni & & \\
\hline & $\mathrm{N}$ & Power density ( $\mathrm{mW} / \mathrm{m}^{3}$ of anodic chamber) & S.D. & $\mathrm{F}$ & $\mathrm{p}$ & Scheffe's post hoc test \\
\hline $350(1)$ & 14 & 0.49 & 0.43 & 25.173 & 0.000 & $(4)=(3)$ \\
\hline $700(2)$ & 8 & 1.16 & 0.31 & & & $(4)>(2)>(1)$ \\
\hline $1000(3)$ & 5 & 1.66 & 0.26 & & & $(3)=(2)>(1)$ \\
\hline $2000(4)$ & 5 & 2.44 & 0.78 & & & \\
\hline Flow rate $(\mu \mathrm{L} / \mathrm{min})$ & & Arthrobacter & polych & mogenes: & & \\
\hline & $\mathrm{N}$ & Power density $\left(\mathrm{mW} / \mathrm{m}^{3}\right.$ of anodic chamber) & S.D. & $\mathrm{F}$ & $\mathrm{p}$ & Scheffe's post hoc test \\
\hline $350(1)$ & 14 & 0.34 & 0.35 & 14.809 & 0.000 & $(4)=(3)=(2)>(1)$ \\
\hline $700(2)$ & 8 & 0.89 & 0.11 & & & \\
\hline $1000(3)$ & 5 & 0.98 & 0.18 & & & \\
\hline $2000(4)$ & 5 & 1.08 & 0.20 & & & \\
\hline
\end{tabular}

Table 5: Comparison of MFC potentials of gram negative and gram positive bacteria at different flow rates (external load resistance of $1000 \Omega$ )

\begin{tabular}{|c|c|c|c|c|c|c|}
\hline Flow rate $=350(\mu \mathrm{L} / \mathrm{min})$ & & & & & & \\
\hline Culture & $\mathrm{N}$ & Mean $(\mathrm{mV})$ & S.D. & $\mathrm{F}$ & $\mathrm{p}$ & Scheffe's post hoc test \\
\hline (1) Pseudomonas putida & 10 & 12.33 & 4.79 & 2.919 & 0.044 & $(1)=(2)=(3)=(4)$ \\
\hline (2) Corynebacterium glutamicum & 10 & 7.71 & 10.52 & & & \\
\hline (3) Comamonas testosteroni & 14 & 17.78 & 9.07 & & & \\
\hline (4) Arthrobacter polychromogenes & 14 & 14.60 & 8.09 & & & \\
\hline \multicolumn{7}{|l|}{ Flow Rate $=700(\mu \mathrm{L} / \mathrm{min})$} \\
\hline Culture & $\mathrm{N}$ & Mean $(\mathrm{mV})$ & S.D. & $\mathrm{F}$ & $\mathrm{p}$ & Scheffe's post hoc test \\
\hline (1) Pseudomonas putida & 8 & 10.50 & 1.75 & 169.668 & 0.000 & $(3)=(4)>(2)=(1)$ \\
\hline (2) Corynebacterium glutamicum & 8 & 7.03 & 1.00 & & & \\
\hline (3) Comamonas testosteroni & 8 & 30.10 & 4.24 & & & \\
\hline (4) Arthrobacter polychromogenes & 8 & 26.65 & 1.70 & & & \\
\hline \multicolumn{7}{|l|}{ Flow Rate $=1000(\mu \mathrm{L} / \mathrm{min})$} \\
\hline Culture & $\mathrm{N}$ & Mean (mV) & S.D. & $\mathrm{F}$ & $\mathrm{p}$ & Scheffe's post hoc test \\
\hline (1) Pseudomonas putida & 5 & 12.64 & 0.38 & 187.453 & 0.000 & $(3)>(4)>(2)=(1)$ \\
\hline (2) Corynebacterium glutamicum & 5 & 9.90 & 0.94 & & & \\
\hline (3) Comamonas testosteroni & 5 & 36.33 & 2.91 & & & \\
\hline (4) Arthrobacter polychromogenes & 5 & 27.85 & 2.70 & & & \\
\hline \multicolumn{7}{|l|}{ Flow Rate $=2000(\mu \mathrm{L} / \mathrm{min})$} \\
\hline Culture & $\mathrm{N}$ & Mean $(\mathrm{mV})$ & S.D. & $\mathrm{F}$ & $\mathrm{p}$ & Scheffe's post hoc test \\
\hline (1) Pseudomonas putida & 5 & 14.04 & 0.91 & 75.323 & 0.000 & $(3)>(4)>(2)=(1)$ \\
\hline (2) Corynebacterium glutamicum & 5 & 11.79 & 0.93 & & & \\
\hline (3) Comamonas testosteroni & 5 & 43.64 & 7.01 & & & \\
\hline (4) Arthrobacter polychromogenes & 5 & 29.27 & 2.74 & & & \\
\hline
\end{tabular}


Table 6: Comparison of MFC power densities of gram negative and gram positive bacteria at different flow rates (external load resistance of $1000 \Omega$ )

\begin{tabular}{|c|c|c|c|c|c|c|}
\hline \multicolumn{7}{|l|}{ Flow rate $=350(\mu \mathrm{L} / \mathrm{min})$} \\
\hline Culture & $\mathrm{N}$ & $\begin{array}{c}\text { Power density }\left(\mathrm{mW} / \mathrm{m}^{3} \text { of anodic }\right. \\
\text { chamber) }\end{array}$ & S.D. & $\mathrm{F}$ & $\mathrm{p}$ & Scheffe's post hoc test \\
\hline (1) Pseudomonas putida & 10 & 0.22 & 0.17 & 1.698 & 0.181 & \\
\hline (2) Corynebacterium glutamicum & 10 & 0.20 & 0.41 & & & \\
\hline (3) Comamonas testosteroni & 14 & 0.49 & 0.43 & & & \\
\hline (4) Arthrobacter polychromogenes & 14 & 0.34 & 0.35 & & & \\
\hline \multicolumn{7}{|l|}{ Flow rate $=700(\mu \mathrm{L} / \mathrm{min})$} \\
\hline Culture & $\mathrm{N}$ & $\begin{array}{l}\text { Power density }\left(\mathrm{mW} / \mathrm{m}^{3} \text { of anodic }\right. \\
\text { chamber) }\end{array}$ & S.D. & $\mathrm{F}$ & $\mathrm{p}$ & Scheffe's post hoc test \\
\hline (1) Pseudomonas putida & 8 & 0.14 & 0.04 & 87.565 & 0.000 & $(3)>(4)>(2)=(1)$ \\
\hline (2) Corynebacterium glutamicum & 8 & 0.06 & 0.02 & & & \\
\hline (3) Comamonas testosteroni & 8 & 1.16 & 0.31 & & & \\
\hline (4) Arthrobacter polychromogenes & 8 & 0.89 & 0.11 & & & \\
\hline \multicolumn{7}{|l|}{ Flow rate $=1000(\mu \mathrm{L} / \mathrm{min})$} \\
\hline Culture & $\mathrm{N}$ & $\begin{array}{c}\text { Power density }\left(\mathrm{mW} / \mathrm{m}^{3} \text { of anodic }\right. \\
\text { chamber) }\end{array}$ & S.D. & $\mathrm{F}$ & $\mathrm{p}$ & Scheffe's post hoc test \\
\hline (1) Pseudomonas putida & 5 & 0.20 & 0.01 & 102.495 & 0.000 & $(3)>(4)>(2)=(1)$ \\
\hline (2) Corynebacterium glutamicum & 5 & 0.12 & 0.02 & & & \\
\hline (3) Comamonas testosteroni & 5 & 1.66 & 0.26 & & & \\
\hline (4) Arthrobacter polychromogenes & 5 & 0.98 & 0.18 & & & \\
\hline \multicolumn{7}{|l|}{ Flow rate $=2000(\mu \mathrm{L} / \mathrm{min})$} \\
\hline Culture & $\mathrm{N}$ & $\begin{array}{l}\text { Power density }\left(\mathrm{mW} / \mathrm{m}^{3} \text { of anodic }\right. \\
\text { chamber) }\end{array}$ & S.D. & $\mathrm{F}$ & $\mathrm{p}$ & Scheffe's post hoc test \\
\hline (1) Pseudomonas putida & 5 & 0.25 & 0.03 & 33.705 & 0.000 & $(3)>(4)>(2)=(1)$ \\
\hline (2) Corynebacterium glutamicum & 5 & 0.18 & 0.03 & & & \\
\hline (3) Comamonas testosteroni & 5 & 2.44 & 0.78 & & & \\
\hline (4) Arthrobacter polychromogenes & 5 & 1.08 & 0.20 & & & \\
\hline
\end{tabular}

Table 7: Comparison of MFC specific powers of gram negative and gram positive bacteria (external load resistance of $1000 \Omega$ )

\begin{tabular}{|c|c|c|c|c|c|c|}
\hline Pure cultures & $\mathrm{N}$ & $\begin{array}{c}\text { Mean } \\
(\mathrm{mW} / \mathrm{kg} \mathrm{COD} / \text { day })\end{array}$ & S.D. & $\mathrm{F}$ & $\mathrm{p}$ & Scheffe's post hoc test \\
\hline (1)Pseudomonas putida & 8 & 0.202 & 0.116 & 18.042 & 0.000 & $(3)=(4)>(2)=(1)$ \\
\hline (2)Corynebacterium gultamicum & 8 & 0.078 & 0.042 & & & \\
\hline (3)Comamonas testosteroni & 7 & 2.825 & 0.206 & & & \\
\hline (4)Arthrobacter polychromogenes & 7 & 1.862 & 1.763 & & & \\
\hline
\end{tabular}

the organic matter content (COD), not on the wastewater flow rate. However, notably, other researchers also reported different optimal HRTs for obtaining better power generation performance of MFC. Li et al. (2008) mentioned that HRT influences the power generation of MFC and the maximum voltage $(0.413 \mathrm{~V})$ and power density $\left(108 \mathrm{~mW} / \mathrm{m}^{2}\right)$ can be obtained at the HRT of $15.5 \mathrm{~h}$. Liu et al. (2008) obtained a maximum power density of $22 \mathrm{~W} / \mathrm{m}^{3}$ at a HRT of $11.3 \mathrm{~h}$. You et al. (2006) also concluded that longer HRT may have a detrimental effect on voltage stability when compared to shorter HRTs. In the current study (Tables 3 and 4), maximum average voltage of $43.64 \mathrm{mV}$ and maximum average power density of 
$2.44 \mathrm{~mW} / \mathrm{m}^{3}$ were obtained at the HRT of $6.6 \mathrm{~h}$ (flow rate $=2000 \mu \mathrm{L} / \mathrm{min}$ ) for Comamonas testosteroni (MFC 3). Therefore, the reactor configuration, wastewater characteristics, applied cultures and operational characteristics may be the factors causing the different results.

The comparisons of potential and power density at different flow rates on gram negative and gram positive bacteria are shown in Tables 5 and 6 . At lower flow rate $(350 \mu \mathrm{L} / \mathrm{min})$, no significant differences on the potential and the power density of MFCs were found between gram negative and gram positive bacteria. At higher flow rate (especially at 1000 and $2000 \mu \mathrm{L} / \mathrm{min}$ ), Comamonas testosteroni showed the highest power generation performance, followed by A. polychromogenes. At higher flow rate (lower HRT), gram negative bacterium, such as Comamonas testosteroni, which has thinner cell wall and lower Zeta potential on cell surface, may discharge the electrons and protons much faster than gram positive bacterium, such as $A$. polychromogenes. In addition, the potentials and the power densities of $P$. putida and Corynebacterium glutamicum were always lower than those of Comamonas testosteroni and $A$. polychromogenes. Behera and Ghangrekar (2009) claimed that higher feed $\mathrm{pH}$ (8.0) may favor higher power production; thus, lower $\mathrm{pH}$ of artificial wastewater for P. putida and Corynebacterium glutamicum might affect their power generation performance. A comparison of specific powers of two gram negative and two gram positive bacteria is shown in Table 7 . The results only show that Comamonas testosteroni and A. polychromogenes can produce more power than $P$. putida and Corynebacterium glutamicum with the utilization of the same amount of COD. No significant difference on the specific power (power production per kilogram COD used) was seen between Comamonas testosteroni and A. polychromogenes and between P. putida and Corynebacterium glutamicum. Therefore, more evidence is required to prove the difference of power generation capability between gram negative and gram positive bacteria in the future.

\section{CONCLUSION}

Continuous-flow MFC combined with biological treatment unit can effectively remove the organic matter from wastewater and simultaneously generate electricity. Each pure culture has different power generation performance under the same operational conditions. However some factors, such as wastewater $\mathrm{pH}$, wastewater flow rate and HRT of reactor, also affect the electrogenic capability of each culture. Maximum average voltage of $43.64 \mathrm{mV}$ and maximum average power density of $2.44 \mathrm{~mW} / \mathrm{m}^{3}$ were obtained at the HRT of $6.6 \mathrm{~h}$ (flow rate $=2000 \mu \mathrm{L}$ / $\mathrm{min}$ ) for Comamonas testosteroni. Good linear relationships between the flow rate and the potential and between the flow rate and the power density on four pure cultures at different external load resistances were found. The current study also showed that Comamonas testosteroni has better power generation performance than $A$. polychromogenes, especially at higher flow rate. Although, P. putida also showed higher power generation than Corynebacterium glutamicum, the difference was not statistically significant. The $\mathrm{pH}$ of wastewater may be one of the major reasons for the difference. It seems that gram negative bacterium displayed higher power generation than gram positive bacterium at higher flow rate (lower HRT). Although the bacteria received the same synthetic wastewater with lower and higher $\mathrm{pH}$ and grew under the same operational conditions, they displayed different power outputs. It is suspected that the difference of their surface charges may be one of the reasons affecting the electrons diffusing into the liquid and to the electrode. Overall, the difference of growth rates between gram negative and gram positive bacteria may also affect their electrogenic capability in MFC. The results of this study showed that more evidence is required to prove the difference of power generation capacity between gram negative and gram positive bacteria in the future.

\section{ACKNOWLEDGEMENTS}

The authors would like to express their gratitude and appreciation to the National Science Council (NSC) of Taiwan for the financial support of this research under the Contract No. NSC-99-2221-E-276-004-.

\section{REFERENCES}

Behera, M.; Ghangrekar, M. M., (2009). Performance of microbial fuel cell in response to change in sludge loading rate at different anodic feed $\mathrm{pH}$. Bioresour. Tech., 100 
(21), 5114-5121 (8 pages).

Biffinger, J. C.; Byrd, J. N.; Dudley, B. L.; Ringeisen, B. R., (2008). Oxygen exposure promotes fuel diversity for Shewanella oneidensis microbial fuel cells. Biosens. Bioelectron., 23 (6), 820-826 (7 pages).

Bond, D. R.; Lovley, D. R., (2003). Electricity production by Geobacter sulfurreducens attached to electrodes. Appl. Environ. Microbiol., 69 (3), 1548-1555 (8 pages).

Chaudhuri, S. K.; Lovley, D. R., (2003). Electricity generation by direct oxidation of glucose in mediatorless microbial fuel cells. Nat. Biotech., 21, 1229-1232 (4 pages).

Chen, Y. H.; Chen, C. Y.; Lee, S. C., (2010). Technology forecasting of new clean energy: The example of hydrogen energy and fuel cell. Afr. J. Bus. Manag., 4 (7), 1372 1380 (9 pages).

Clesceri, L. S.; Greenberg, A. E.; Eaton, A. D., (2001). Standard methods for the examination of water and wastewater, American Public Health Association (APHA), American Water Works Association (AWWA) and Water Environment Federation (WEF).

Debabov, V. G., (2008). Electricity from Microorganisms. Microbiol., 77 (2), 123-131 (9 pages).

Du, Z.; Li, H.; Gu, T., (2007). A state of the art review on microbial fuel cells: A promising technology for wastewater treatment and bioenergy. Biotech. Adv., 25 (5), 464-482 (19 pages).

El Diwani, G.,; El Rafie, S.; Hawash, S., (2009). Degradation of 2, 4, 6-trinitotoluene in aqueous solution by ozonation and multi-stage ozonation biological treatment. Int. J. Environ. Sci. Tech., 6 (4), 619-628 (10 pages).

Finch, A. S.; Mackie, T. D.; Sund, C. J.; Sumner, J. J., (2011). Metabolite analysis of Clostridium acetobutylicum: Fermentation in a microbial fuel cell. Bioresour. Tech., 102 (1), 312-315 (4 pages).

Ghangrekar, M. M.; Shinde, V. B., (2007). Performance of membrane-less microbial fuel cell treating wastewater and effect of electrode distance and area on electricity production. Bioresour. Tech., 98 (15), 2879-2885 (7 pages).

Juang, D. F.; Chiou, L. J., (2007). Microbial population structures in activated sludge before and after the application of synthetic polymer. Int. J. Environ. Sci. Tech., 4 (1), 119-125 (7 pages).

Kim, B. H.; Kim, H. J.; Hyun, M. S.; Park, D. H., (1999). Direct electrode reaction of $\mathrm{Fe}$ (III) reducing bacterium, Shewanella putrefacience. J. Microbiol. Biotech., 9, 127131 (5 pages).

Kim, H. J.; Park, H. S.; Hyun, M. S.; Chang, I. S.; Kim, M.; Kim, B. H., (2002). A mediator-less microbial fuel cell using a metal reducing bacterium, Shewanella putrefacians. Enzyme Microb. Tech., 30, 145-152 (8 pages).

Lee, S. C.; Shih, L. H., (2010). Renewable energy policy evaluation using real option model-The case of Taiwan. Energy Econ., 32 (Supplement 1), 567-578 (12 pages).

Li, Z. L.; Yao, L.; Kong, L. C.; Liu, H., (2008). Electricity generation using a baffled microbial fuel cell convenient for stacking. Bioresour. Tech., 99 (6), 1650-1655 (6 pages).
Liu, H.; Cheng, S.; Huang, L.; Logan, B. E., (2008). Scaleup of membrane-free single-chamber microbial fuel cells. J. Power Sources, 179 (1), 274-279 (6 pages).

Logan, B. E.; Regan, J. M., (2006). Electricity-producing bacterial communities in microbial fuel cells. Trends Microbiol., 14 (12), 512-518 (7 pages).

Mathuriya, A. S.; Sharma, V. N., (2009). Bioelectricity production from paper industry waste using a microbial fuel cell by Clostridium species. J. Biochem. Tech., 1 (2), 49-52 (4 pages).

Min, B.; Cheng, S.; Logan, B. E., (2005). Electricity generation using membrane and salt bridge microbial fuel cells. Water Res., 39 (9), 1675-1686 (12 pages).

Mohan, S. V.; Mohanakrishna, G.; Sarma, P. N., (2010). Composite vegetable waste as renewable resource for bioelectricity generation through non-catalyzed openair cathode microbial fuel cell. Bioresour. Tech., 101 (3), 970-976 (7 pages).

Park, H. S.; Kim, B. H.; Kim, H. S.; Kim, H. J.; Kim, G. T.; Kim, M.; Chang, I. S.; Park, Y. K.; Chang, H. I., (2001). A novel electrochemically active and Fe(III)-reducing bacterium phylogenetically related to Clostridium butyricum isolated from a microbial fuel cell. Anaerobe, 7 (6), 297-306 (10 pages).

Rabaey, K.; Boon, N.; Siciliano, S. D.; Verhaege, M.; Verstraete, W., (2004). Biofuel cells select for microbial consortia that self-mediate electron transfer. Appl. Environ. Microbiol., 70 (9), 5373-5382 (10 pages).

Rabaey, K.; Verstraete, W., (2005). Microbial fuel cells: novel biotechnology for energy generation. Trends Biotech., 23 (6), 291-298 (8 pages).

Refaat, A. A., (2009). Correlation between the chemical structure of biodiesel and its physical properties. Int. J. Environ. Sci. Tech., 6 (4), 677-694 (18 pages).

Refaat, A. A., (2010). Different techniques for the production of biodiesel from waste vegetable oil. Int. J. Environ. Sci. Tech., 7 (1), 183-213 (31 pages).

Rodrigo, M. A.; Cañizares, P.; Lobato, R.; Paz, R.; Sáez, C.; Linares, J. J., (2007). Production of electricity from the treatment of urban waste water using a microbial fuel cell. J. Power Sources, 169 (1), 198-204 (7 pages).

Schroder, U.; Nieben, J.; Scholz, F., (2003). A generation of microbial fuel cells with current outputs boosted by more than one order of magnitude. Angew. Chem. Int. Ed. Engl., 42 (25), 2880-2883 (4 pages).

Sun, J.; Hu, Y.; Bi, Z.; Cao, Y., (2009). Improved performance of air-cathode single-chamber microbial fuel cell for wastewater treatment using microfiltration membranes and multiple sludge inoculation. J. Power Sources, 187 (2), 471-479 (9 pages).

Watson, V. J.; Logan, B. E., (2010). Power production in MFCs inoculated with Shewanella oneidensis MR-1 or mixed cultures. Biotech. Bioeng., 105 (3), 489-498 (10 pages).

You, S. J.; Zhao, Q. L.; Jiang, J. Q.; Zhang, J. N., (2006). Treatment of domestic wastewater with simultaneous electricity generation in microbial fuel cell under continuous operation. Chem. Biochem. Eng. Q., 20 (4), 407-412 (6 pages) 
Zhang, T.; Cui, C.; Chen, S.; Yang, H.; Shen, P., (2008). The direct electrocatalysis of Escherichia coli through electroactivated excretion in microbial fuel cell. Electrochem. Commun., 10 (2), 293-297 (5 pages).

\section{AUTHOR(S) BIOSKETCHES}

Juang, D. F., Ph.D., Professor, Department of Health Business Administration, Meiho University, 23, Pingguang Rd., Neipu, Pingtung 912, Taiwan, R.O.C. Email: x00002060@email.meiho.edu.tw

Yang, P. C., Ph.D., Otologist; Otorhinolaryngologic Department, Cheng Ching General Hospital, 24F, 230, Ming Chuan Second Road, Kaohsiung 806, Taiwan. Email: dfjuang@seed.net.tw

Lee, C. H., Ph.D., Assistant Professor, Department of Health Business Administration, Meiho University, 23, Pingguang Rd., Neipu, Pingtung 912, Taiwan, R.O.C. Email: x00002167@meiho.edu.tw

Hsueh, S. C., Ph.D., Lecturer, Department of Health Business Administration, Meiho University, 23, Pingguang Rd., Neipu, Pingtung 912, Taiwan, R.O.C. Email: x00003113@meiho.edu.tw

Kuo, T. H., Ph.D.,Nephrology Director, New Taipei City Hospital Banqiao Branch, 198, Yingshi Rd., Banqiao Dist., New Taipei City 220,

Taiwan, R.O.C. Email: nephguo@yahoo.com.tw

How to cite this article: (Harvard style)

Juang, D. F.; Yang, P. C.; Lee, C. H.; Hsueh, S. C.; Kuo, T. H., (2011). Electrogenic capabilities of gram negative and gram positive

bacteria in microbial fuel cell combined with biological wastewater treatment. Int. J. Environ. Sci. Tech., 8 (4), $781-792$. 